\title{
PENGARUH FDR, DER, DAN CURRENT RATIO TERHADAP PROFITABILITY DENGAN NPF SEBAGAI VARIABEL MODERATING
}

\author{
Lora Lorenza $^{1}$ \& Saiful Anwar ${ }^{2}$ \\ ${ }^{1 \& 2}$ Fakultas Ekonomi dan Bisnis Islam, IAIN Salatiga \\ Email: loralorenza.psfebi@gmail.com,saifulanwarmieta@iainsalatiga.ac.id
}

\begin{abstract}
ABSTRAK
Penelitian ini bertujuan untuk memahami indikator yang dapat mempengaruhi profitabilitas ROA dalam bank umum syariah. Indikator yang digunakan pada penelitian ini ialah Financing To Deposit Ratio, Debt To Equity Ratio, dan Current Ratio dengan Non Performing Financing sebagai variabel moderating pada bank umum syariah di Indonesia periode 2015-2019. Total sampel pada penelitian ini yaitu sebanyak 11 bank umum syariah di Indonesia yang dipilih menggunakan metode Purposive Sampling. Penelitian ini menggunakan jenis penelitian data panel dan diuji menggunakan analisis regresi linear berganda. Hasil penelitian menunjukan bahwa secara simultan FDR, DER dan Current Ratio terdapat pengaruh secara signifikan terhadap ROA. Namun secara parsial FDR dan DER memiliki pengaruh negatif terhadap ROA, Current Ratio berpengaruh positif terhadap ROA. Berdasarkan uji MRA (Moderated Regression Analysis), NPF dapat memperkuat pengaruh FDR terhadap ROA, namun NPF tidak dapat memoderasi DER terhadap ROA, Sedangkan NPF dapat melemahkan Current Ratio terhadap ROA.
\end{abstract}

Kata Kunci: FDR, DER, Current Ratio, ROA.

\begin{abstract}
This study aims to understand the indicators that can affect the profitability of ROA in Islamic commercial banks. The indicators used in this study are Financing To Deposit Ratio, Debt To Equity Ratio, and Current Ratio with Non-Performing Financing as moderating variables in Islamic Commercial Banks in Indonesia for the 2015-2019 period. The total sample in this study was 11 Islamic commercial banks in Indonesia which were selected using the purposive sampling method. This study used a panel data research type and was tested using multiple linear regression analysis. The results showed that simultaneously FDR, DER, and Current Ratio had a significant effect on ROA. However, partially FDR and DER have a negative effect on ROA, the Current Ratio has a positive effect on ROA. Based on the MRA (Moderated Regression Analysis) test, NPF can strengthen the effect of FDR on ROA, but NPF cannot moderate DER to ROA, whereas NPF can weaken the Current Ratio to ROA.
\end{abstract}

Keywords: FDR, DER, Current Ratio, ROA. 


\section{PENDAHULUAN}

Pada era digitalisasi saat ini setiap negara mengalami pertumbuhan. Aspek yang semakin meningkat pesat seperti perekonomian dan lembaga keuangan. Berkembangnya aspek tersebut tak terlepas dari kondisi perekonomian yang stabil atau terus meningkat. Salah satu yang menjadi penyokong terjadinya perekonomian yang stabil karena adanya kenaikan profitabilitas Return On Asset (ROA) di perbankan syariah yang termasuk pada Otoritas Jasa Keuangan cukup signifikan. Peningkatan profitabilitas Return On Asset (ROA) dapat kita lihat pada peningkatan kurva
Return On Asset (ROA) dalam lima tahun terakhir 2015-2019. Namun tidak dapat dipungkiri meskipun profitabilitas Return On Asset (ROA) pada perbankan syariah saat ini terus mengalami kenaikan, Return On Asset (ROA) yang didapatkan oleh bank syariah masih jauh dibelakang perbankan konvensional.

Karena masyarakat Indonesia merupakan mayoritas beragama Muslim, sehingga perbankan syariah diharapkan mampu untuk terus bersaing dengan perbankan konvensional serta dapat terus meningkatkan segala aspek agar setara dengan perbankan konvensional yang telah ada.

Tabel 1. Data Return On Asset (ROA) Bank Umum Syariah

\begin{tabular}{cccccc}
\hline Tahun & 2015 & 2016 & 2017 & 2018 & 2019 \\
\hline ROA & 0,49 & 0,63 & 0,63 & 1,28 & 1,73 \\
\hline
\end{tabular}

\section{Sumber:Otoritas Jasa Keuangan (2019)}

Perbankan syariah begitu identik terhadap sistem pembiayaan dan bagi hasilnya seperti, pembiayaan mudharabah pada bank BRI Syariah, BNI Syariah dan bank lainnya. Karena, kedua karakteristik tersebut sama-sama memberikan profitabilitas baik terhadap pihak bank ataupun pihak customer.

Berdasarkan produk dan pelayanan jasa yang bermacam-macam skema keuangan perbankan syariah jadi lebih bervariatif. Sistem pada perbankan yang kredibel membuat perbankan syariah menjadi alternatif yang banyak dipilih oleh masyarakat Indonesia (Otoritas Jasa Keuangan, 2019).

Perkembangan pada bank syariah dapat kita lihat dari jumlah bank umum syariah pada saat ini. Pertama kali sejak tahun 1998 hingga sekarang perkembangan keuangan syariah di Indonesia selalu signifikan. Hal itu tersebut terlihat dari data yang rutin disampaikan oleh Otoritas Jasa Keuangan seperti berikut ini:

Tabel 2. Data perkembangan Bank Umum Syariah Indonesia

\begin{tabular}{cccccc}
\hline Tahun & 2015 & 2016 & 2017 & 2018 & 2019 \\
\hline BUS & 12 & 13 & 13 & 14 & 14 \\
\hline \multicolumn{7}{c}{ Sumber : Otoritas Jasa Keuangan (2019) } \\
\end{tabular}

Persaingan dunia bisnis dewasa saat ini sedang mengalami peningkatan. Sehingga trade-off diantara likuiditas dengan profitabilitas menjadi permasalahan yang paling sering ditemui oleh perusahaan karena berkesinambungan dengan keuangan. Profitabilitas biasanya dipergunakan untuk menganalisa kesanggupan suatu perusahaan (bank) dalam memperoleh laba perolehan saat menggunakan modal sendiri dan modal asing agar dapat memperoleh laba tersebut (Riyanto, 1998).

Salah satu rasio dari likuiditas yang dipergunakan dalam menganalisa 
tingkat keamanan (margin safety) kreditur jangka pendek yaitu Current Ratio (CR). Keputusan perusahaan dalam mengoptimalkan modal kerja sehingga angka Current Ratio (CR) meningkat dan likuiditas dapat stabil, namun hal ini mungkin akan berpengaruh terhadap profitabilitas, karena akan adanya idlecash yang tidak dijalankan dengan maksimal dalam kepentingan perusahaan (Jungjungan et al, 2015).

Untuk mengoptimalisasikan hasil dari berbagai macam produk pada bank umum syariah Indonesia agar tetap menghasilkan profitabilitas keuangan yang tinggi terhadap perusahaan. Maka pada riset ini digunakan 2 macam variabel, terdiri dari variabel independen dan variabel depeden. Variabel independen yang penulis pilih ialah Financing to Deposit Ratio (FDR) selaku variabel pertama berfokus pada pengukuran jumlah pembiayaan yang didanai dengan jumlah modal yang dimiliki atau digunakan. Kemudian Debt to Equity Ratio (DER) selaku variabel kedua yaitu kemampuan pada modal sendiri dalam membiayai hutang. Terakhir menggunakan Current Ratio (CR) sebagai variabel ketiga yang berfokus pada analisa kemampuan perusahaan ketika membayar hutang. Ditambahi dengan Non Performing Financing (NPF) yaitu pembiayaan yang bermasalah sebagai variabel pemoderasinya.

Adapula variabel dependen yang penulis pilih ialah Profitability Return on Asset (ROA). Return on Asset (ROA) merupakan rasio yang paling sering digunakan sebagai alat analisa, karena Return on Asset (ROA) diduga mampu menggambarkan tingkat keberhasilan perusahaan dalam memperoleh laba. Return on asset (ROA) juga merupakan rasio profitabilitas yang paling mudah dihitung dan dipahami. Sehingga profitabilitas Return on asset (ROA) menjadi hal yang paling sensitif ketika menganalisa kemampuan manajemen yang berpengaruh terhadap keuangan perusahaan.

Pendapat ini sependapat oleh adanya penelitian yang dilakukan oleh Ikhwal (2016), bahwa Return On Asset (ROA) mempunyai pengaruh yang signifikan terhadap profitabilitas. Faktor lain yang menjadi pendukung Return On Asset (ROA) pada penelitian kali ini karena Bank Indonesia sudah memutuskan Return On Asset (ROA) sebagai salah satu rasio untuk mengukur profitabilitas suatu perusahaan (bank) (Almunawwarah \& Marliana, 2018).

\section{TINJAUAN PUSTAKA}

\section{Agency Theory}

Teori keagenan ialah kerjasama diantara dua pihak atau lebih yang terikat terhadap kontrak, dimana pihak yang agen (agent), memiliki kewajiban dalam pengambilan keputusan dan menggantikan kepentingan yang dipilih (principals) oleh pihak lainya yang secara umum berkaitan dengan penyelesaian masalah (Asyik, 2016).

Agar pihak agen dapat melaksanakan tugasnya, maka prinsipal akan melimpahkan wewenang untuk menentukan keputusan hingga batas tertentu pada agen. Perusahaan berbasis hukum merupakan bentuk dari ikatan keagenan. Kerjasama ini didasari berdasarkan kontrak terlaksana antara pihak manajemen selaku agent dan owner atau investor sebagai principals.

\section{Profitabilitas}

Rasio profitabilitas menurut Kasmir (2014), adalah gambaran rasio yang digunakan sebagai tolak ukur suatu bagi perusahaan saat memperoleh laba. Rasio ini menggambarkan suatu barometer pada tingkat kinerja manajemen pada bank atau perusahaan. Pada analisa laporan keuangan, rasio profitabilitas yakni cerminan pada kapabilitas 
perusahaan ketika memperoleh laba dan memanfaatkan aset ataupun modal perusahaan. Dapat dipastikan jika rasio ini mengalami peningkatan maka akan semakin lebih baik karena laba yang diperoleh semakin besar.

Return On Asset (ROA) adalah suatu rasio keuntungan bersih pajak, rasio ini mampu dijadikan suatu perbandingan dalam menimbang seberapa besar kemampuan tingkat pengembalian aset yang perusahaan miliki (Riyanto, 1998).

Menurut Ikatan Bankir Indonesia perolehan laba dengan kualitas yang baik, menjadi suatu pembuktian bahwasanya suatu perusahaan memiliki kemampuan yang kredibel dalam pemanfaatan modal, asset, dan bahkan operasional perusahaan yang efisien (Martiningtiyas \& Nitinegeri, 2020). Adapun rumus Return On Asset (ROA) adalah sebagai berikut:

$$
\mathrm{ROA}=\frac{\text { Laba Bersih }}{\text { Total Aset }} \times 100 \%
$$

\section{Financing to Deposit Ratio}

Sistem perbankan syariah tidak mengenal hutang (loan) karena pada bank syariah hanya mengenal istilah financing atau pembiayaan. Financing to Deposit Ratio (FDR) yakni salah satu rasio untuk digunakan sebagai perkiraan komposisi jumlah pembiayaan saat dialokasikan sesuai pada jumlah dana atau modal yang dimiliki maupun dimanfaatkan (Maysarah \& Kharisma 2020). Penghitungan Financing to Deposit Ratio (FDR) bisa digunakan sebagai indikator pengukur kesanggupan bank ketika membayar lagi penarikan yang dilakukan oleh nasabah atas penggunaan kredit sebagai asal likuiditas.

Ketika kemampuan likuiditasnya yang rendah akan menyebabkan rasio Financing to Deposit Ratio (FDR) yang semakin tinggi. Namun dampak lain dari tingginya angka Financing to Deposit Ratio (FDR) juga memperlihatkan penerimaan dana bank yang besar. Cara perhitungan Financing to Deposit Ratio:

$$
\mathrm{FDR}=\frac{\text { Total Volume Pembiayaan }}{\text { Total Penerimaan Dana }} \times 100 \%
$$

\section{Deb to Equity Ratio}

Hutang pada dasarnya berfungsi untuk menjadi pendongkrak manajemen dalam meningkatkan kinerja keuangan perusahaan. Karena ketika suatu perusahaan sekedar mengutamakan pemanfaatan modal saja maka akan terjadinya kesulitan dalam pelaksanaan operasional. Hutang sendiri berperan sebagai penyokong perusahaan ketika menjalankan ekspansi bisnis. Namun jika posisi total hutang melebihi total dari ekuitas maka perusahaan akan menanggung risiko yang cukup tinggi sehingga dibutuhkan suatu rasio khusus agar tingkat kinerja yang diinginkan terpenuhi (Palimbong, 2016).

Rasio khusus untuk menjadi salah satu rasio penting yang digunakan sebagai kaca perbandingan bagi investor adalah Debt to Equity Ratio, karena Debt to Equity Ratio (DER) yang biasa disebut juga sebagai rasio utang pada modal atau biasa dikatakan sebagai rasio hutang modal.

Debt to Equity Ratio ialah rasio pada keuangan yang dipergunakan dalam perbandingan diantara hutang dan ekuitas. Jumlah ekuitas dan jumlah hutang pada operasional suatu perusahaan wajib berada dijumlah yang sepadan atau memadai (Sari \& Budiasih, 2014).

Debt to Equity Ratio (DER) ialah rasio keuangan utama pada suatu perusahaan. Karena digunakan pula untuk mengukur letak posisi keuangan pada suatu perusahaan menggunakan rumus tersendiri (Sofiani et al, 2018) rumusnya adalah:

$$
\mathrm{DER}=\frac{\text { Total } \text { Hutang }}{\text { Ekuitas }} \times 100 \%
$$




\section{Current ratio}

Current Ratio atau rasio lancar ialah salah satu dari bagian rasio likuiditas yang dipergunakan untuk pengukuran terhadap kinerja keuangan pada necara likuiditas suatu perusahaan. Rasio lancar biasanya memperlihatkan kesanggupan perusahaan dalam melunasi tuntutan hutang jangka pendek selama satu tahun depan (Saragih, 2015).

Menurut Kasmir (2014), Current Ratio ialah rasio yang digunakan sebagai tolak ukur kemampuan suatu perusahaan dalam melakukan pembayaran hutang jangka pendeknya yang mendekati waktu maksimal pembayaran secara menyeluruh. Dalam makna lain terdapat seberapa banyakkah jumlah aktiva lancar yang dimiliki untuk melakukan pelunasan kewajiban yang mendekati waktu maksimal pembayaran. Berikut ini adalah rumus rasio lancar.

$$
\mathrm{CR}=\frac{\text { Current Asset }}{\text { Current Liabilities }} \times 100 \%
$$

\section{Non Performing Financing}

Non Performing Financing ialah rasio dalam pengukuran risiko pada kredit, dilakukan dengan melakukan perbandingan antara kredit macet dan jumlah pemberian kredit (Kasmir, 2014). Non Performing Financing (NPF) mempunyai tujuan agar dapat memperhitungkan permasalahan pada pemberian pembiayaan oleh pihak bank. Karena jika rasio ini mengalami peningkatan, maka memperlihatkan peringkat suatu pembiayaan pada bank syariah memburuk atau menurun.

\section{Non Performing Financing} (NPF) diperhitungkan dengan spesifikasi penilaian yang dimulai dari tingkatan pertama hingga tingkatan kelima. Non Performing Financing (NPF) akan berada pada tingkatan pertama (satu) ketika nilai Non Performing Financing (NPF) berada pada posisi kurang dari $2 \%$. Non
Performing Financing (NPF) akan berada pada tingkatan kedua ketika nilai Non Performing Financing (NPF) berada diposisi 2\% hingga 5\%. Non Performing Financing (NPF) berada pada tingkatan ke-3 (ketiga) ketika nilai dari Non Performing Financing (NPF) berkisar diantara 5\% hingga $8 \%$. Ketika berada pada tingkatan ke-4 (keempat) Ketika nilai Non Performing Financing (NPF) berkisar diantara $8 \%$ hingga $12 \%$. Tingkatan terakhir ialah ketika nilai Non Performing Financing (NPF) berada diposisi terendah yaitu tingkatan kelima dengan perolehan yang lebih besar dari 12\% (Putranta \& Ambarwati, 2019). Perhitungan atau pengukuran Non Performing Financing (NPF) dapat menggunakan rumus :

$$
\mathrm{NPF}=\frac{\text { Pembiayaan Bermasalah }}{\text { Total Pembiayaan }} \times 100 \%
$$

Penelitian terdahulu mengenai isu Non Performing Financing (NPF) sebagai pemoderasi diantara Financing to Deposit Ratio (FDR) terhadap Return On Asset (ROA). Perolehan hasil akhir yang diperoleh berdasarkan uji Moderated Regression Analysis (MRA) yang dilakukan oleh (Taufik, 2017) disimpulkan bahwasanya variabel Financing to Deposit Ratio (FDR) tidak pengaruh terhadap Return On Asset (ROA) dan varibel Non Performing Financing (NPF) dapat memoderasi antara Financing to Deposit Ratio (FDR) dan profitabilitas (ROA) secara Negatif. Pada penelitian terdahulu belum ditemukannya bagaimana pengaruh Non Performing Financing (NPF) dalam memoderasi Debt to Equity Ratio (DER) dan Current Ratio (CR) terhadap Return On Asset (ROA), sehingga penelitian ini dapat menjadi acuan bagi penelitian selanjutnya.

\section{METODE PENELITIAN}

\section{Jenis Penelitian}

Penelitian ini merupakan jenis penelitian kuantitatif. Spektrum pengukuran dalam riset ini menggunakan 
uji hipotesis data sekunder yaitu data panel. Data sekunder pada riset ini mencakup laporan keuangan tahunan serta laporan yang diterbitkan oleh Bank Umum Syariah (BUS) selama periode 2015-2019 oleh Otoritas Jasa Keuangan, serta dari website resmi masing-masing Bank Umum Syariah yang dibutuhkan.

\section{Objek dan Subjek Penelitian}

Objek penelitian ini adalah Bank Umum Syariah dengan lima tahun periode 2015-2016. Dengan menggunakan 3 jenis variabel yaitu (1) Variabel independen yaitu variabel yang mempengaruhi atau penyebab terjadinya perubahannya pada variabel dependen (terikat) dalam riset ini terdiri dari Financing to Deposit Ratio (FDR), Debt to Equity Ratio (DER), dan Current Ratio (CR). (2) Variabel dependen yaitu varibel yang terkena akibat atau terpengaruh karena dipengaruhi oleh variabel independen (bebas) dalam riset ini Return On Asset (ROA). (3) Variabel moderasi berada diantara variabel independen dengan variabel dependen, mampu memperkuat atau meningkatkan bahkan mampu melemahkan varibel independen. Variabel moderating pada riset ini yaitu Non Performing Financing (Z).

\section{Populasi dan Sampel}

Penelitian ini menggunakan keseluruhan Bank Umum Syariah sebagai populasi total populasi yang digunakan yaitu 14 Bank Syariah. Dari total populasi didapatkan 11 Bank Syariah yang memenuhi kriteria dari purposive sampling. Metode ini ialah metode penetuan sampel berdasarkan persyaratan tertentu yaitu, (1) Bank bagian dari Bank Umum Syariah Indonesia dan sudah mempunyai laporan keuangan yang berisikan data penelitian ini yakni FDR, DER, Current Ratio, NPF dan ROA. (2) Laporan keuangan telah dikutip pada website milik Otoritas Jasa Keuangan serta pada website bank syariah yang bersangkutan periode 2015-2019.

\section{Teknik Pengumpulan Data}

Pengumpulan data dilaksanakan melalui pemantauan tak langsung data ini dapat diperoleh melalui kumpulan informasi mengenai bank yang bersangkutan yang tercantum pada website resmi bank atau pun melalui annual report yang terdapat pada Otoritas Jasa Keuangan. Teknik pengumpulan data penelitian ini melalui tiga metode yaitu:

Pertama, library research yaitu proses penggabungan data-data yang diperlukan melalui pengumpulan teori dari buku dan sumber lainnya sebagai referensi, literatur ataupun acuan baik berupa laporan keuangan ataupun sumber yang berkesinambungan.

Kedua, field research yaitu pengamatan secara langsung pada laporan keuangan agar mendapatkan data pasti yakni kumpulan data sekunder dan sudah diterbitkankan oleh Otoritas Jasa Keuangan (OJK) ataupun website resmi dari setiap Bank Umum Syariah.

Ketiga, internet research yaitu pengumpulan jurnal penelitian yang diperlukan karena adanya referensi yang tertinggal seiring berjalannya waktu sedangkan perkembangan ilmu saat ini selalu mengalami peningkatan.

\section{HASIL DAN PEMBAHASAN}

\section{Deskripsi Data}

Riset ini menjadikan Bank Umum Syariah (BUS) yang terdapat dalam Otoritas Jasa Keuangan (OJK) tahun 2015-2019 sebagai objek penelitian terpilih. Setelah diteliti secara deskriptif statistik, riset ini memperoleh sebanyak 55 data penelitian. Pada riset ini, laporan keuangan tahunan yang digunakan berasal dari Annual Report Bank Umum Syariah (BUS) dengan kriteria pengambilan sampel sejak tahun 2015-2019. 
Tabel 3. Hasil Uji Deskripsi Statistik

\begin{tabular}{lrrrrr}
\hline \multicolumn{1}{c}{ X1 } & $\mathbf{X 2}$ & $\mathbf{X 3}$ & $\mathbf{Y}$ & \multicolumn{1}{c}{ Z } \\
\hline Mean & 87.86345 & 1.414545 & 6.739818 & 1.595636 & 4.390182 \\
\hline Median & 90.10000 & 1.200000 & 6.000000 & 0.950000 & 3.870000 \\
\hline Maximum & 104.7500 & 3.500000 & 17.22000 & 13.60000 & 22.04000 \\
\hline Minimum & 71.87000 & 0.340000 & 3.170000 & -10.77000 & 0.100000 \\
\hline Observations & 55 & 55 & 55 & 55 & 55 \\
\hline \multicolumn{7}{c}{ Sumber: Data Olahan (2021) }
\end{tabular}

Uji Statistik

Koefisien Determinasi $\left(\mathbf{R}^{2}\right)$

Tabel 4. Hasil Uji $\mathbf{R}^{2}$

\begin{tabular}{lr}
\hline R-squared & 0.894183 \\
\hline Adjusted R-squared & 0.849629
\end{tabular}

\section{Sumber: Data Olahan (2021)}

Koefisien determinasi digunakan sebagai penilain terhadap kemampuan seluruh variabel independen dalam menjelaskan variabel dependen. Nilai adjusted $R$-Square riset ini ialah 0,849629 menjelaskan bahwasanya variasi dari variabel independen mampu mempengaruhi variabel dependen sebesar $84,9629 \%$ atau setara $84,96 \%$, sedangkan sebesar $15,04 \%$ dipengaruhi oleh variabel lain yang tidak digunakan dalam penelitian ini.

Uji Statistik F

\section{Tabel 5. Hasil Uji F} 20.06944

F-statistic 0.000000

\section{Sumber: Data Olahan (2021)}

Berdasarkan nilai prob (f-statistic) pada uji model regresi memperoleh nilai sebesar $0,000000<0,05$. Sehingga dalam riset ini dapat disimpulkan bahwa variabel independen yaitu Financing to Deposit
Ratio (FDR), Debt to Equity Ratio (DER), dan Current Ratio (CR) dapat berpengaruh secara simultan dan signifikan terhadap variabel dependen.

Uji Statistik T

Tabel 6. Hasil Uji T

\begin{tabular}{lrrr}
\hline \multicolumn{1}{c}{ Variabel } & Coefficient & T-Statistic & \multicolumn{1}{c}{ Prob } \\
\hline $\mathrm{C}$ & 5.222870 & 1.412253 & 0.1660 \\
\hline $\mathrm{X} 1$ & -0.046689 & -1.116203 & 0.2713 \\
\hline $\mathrm{X} 2$ & -0.503676 & -0.472742 & 0.6391 \\
\hline $\mathrm{X} 3$ & 0.240875 & 1.206379 & 0.2351 \\
\hline $\mathrm{X} 1 \_\mathrm{Z}$ & 0.010135 & 3.250424 & 0.0024 \\
\hline $\mathrm{X} 2 \_\mathrm{Z}$ & -0.236343 & -1.856664 & 0.0711 \\
\hline $\mathrm{X} 3 \_\mathrm{Z}$ & -0.089293 & -3.019272 & 0.0045 \\
\hline
\end{tabular}

Sumber: Data Olahan (2021)

Interpretasi Uji statistik T ialah:

1. Nilai koefisien Financing to Deposit Ratio (FDR) ialah -0.046689 pada arah negatif, artinya Financing to Deposit Ratio (FDR) berpengaruh negatif terhadap Return On Asset (ROA).
2. Nilai koefisien Debt to Equity Ratio (DER) ialah -0.503676 pada arah negatif, artinya Financing to Deposit Ratio (FDR) berpengaruh negatif terhadap Return On Asset (ROA). 
3. Nilai koefisien (CR) ialah 0.240875 pada arah negatif, artinya Current Ratio (CR) berpengaruh negatif terhadap Return On Asset (ROA).

4. Nilai koefisien Financing to Deposit Ratio (FDR) ialah 0.010135 pada arah negatif dengan probabilitas $0.0024>0,05 \quad(\alpha), \quad$ artinya $\mathrm{NPF}$ memperkuat pengaruh Financing to Deposit Ratio (FDR) terhadap Return On Asset (ROA).

5. Nilai koefisien Debt to Equity Ratio (DER) ialah -0.236343 pada arah negatif dengan probabilitas
$0.0711>0,05 \quad(\alpha), \quad$ artinya Non Performing Financing (NPF) tidak mampu memoderasi pengaruh Debt to Equity Ratio (DER) terhadap Return On Asset (ROA).

6. Nilai koefisien Current Ratio (CR) ialah -0.089293 pada arah negatif dengan probabilitas $0.0045>0,05(\alpha)$, artinya NPF memperlemah pengaruh Current Ratio (CR) terhadap Return On Asset (ROA).

\section{Uji Asumsi Klasik}

Uji Normalitas

\section{Gambar 1. Hasil Uji Normalitas}

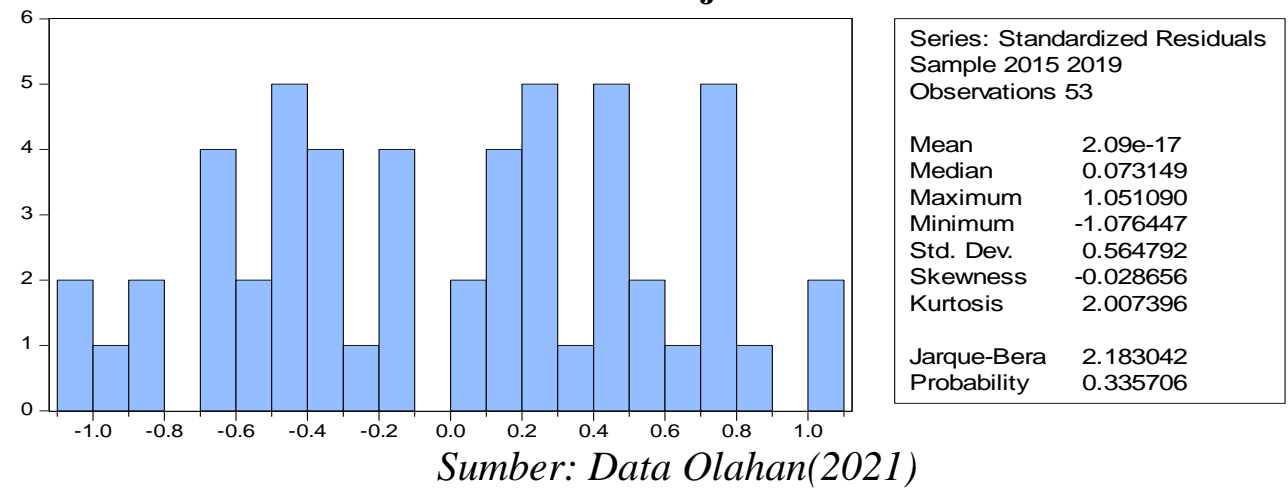

Uji normalitas pada riset ini berdasarkan hasil penelitian ini dapat dilakukan log pada varibel dependen dikatakan bahwa pada uji ini riset maka nilai Jarque-Bera yang diperoleh memperoleh hasil yang normal.

sebesar 2.183042 dengan nilai Probabilitas 0,335706 > 0,05 maka Uji Multikolinearitas

Tabel 7. Hasil Uji Multikolineritas

\begin{tabular}{lrrrr}
\hline & X1 & X2 & X3 & \multicolumn{1}{l}{$\mathbf{Z}$} \\
\hline $\mathbf{X 1}$ & 1.000000 & -0.658455 & 0.412777 & 0.081031 \\
\hline $\mathbf{X 2}$ & -0.658455 & 1.000000 & -0.586271 & 0.159288 \\
\hline $\mathbf{X 3}$ & 0.412777 & -0.586271 & 1.000000 & 0.148706 \\
\hline $\mathbf{Z}$ & 0.081031 & 0.159288 & 0.148706 & 1.000000 \\
\hline
\end{tabular}

Sumber: Data Olahan (2021)

Berdasarkan perolehan nilai dari ini dapat disimpulkan tidak adanya data tersebut memperlihatkan bahwa tidak terjadinya korelasi silang yang bernilai lebih dari 0,70 , maka pada penelitian kali masalah multikolinearitas.

\section{Uji Heteroskedastisitas}


Tabel 8. Hasil Uji Heterokedastisitas

\begin{tabular}{cc}
\hline Variabel & Prob. \\
\hline $\mathrm{C}$ & 0.2065 \\
\hline $\mathrm{X} 1$ & 0.2740 \\
\hline $\mathrm{X} 2$ & 0.2055 \\
\hline $\mathrm{X} 3$ & 0.7320 \\
\hline $\mathrm{X} 1 \_\mathrm{Z}$ & 0.8435 \\
\hline $\mathrm{X} 2 \_\mathrm{Z}$ & 0.0937 \\
\hline $\mathrm{X} 3 \_\mathrm{Z}$ & 0.0897 \\
\hline Sumber: Data Olahan (2021)
\end{tabular}

Berdasarkan nilai Probabilitas ini tersebut tidak terjadi melalui uji glesjer pada tabel di atas heteroskedastisitas. semua angka hasil menunjukan nilai $>0,05$ maka dapat dijelaskan bahwa pada riset

\section{Uji Autokorelasi}

Tabel 9. Hasil Uji Normalitas

\begin{tabular}{|c|c|}
\hline Variabel & Prob \\
\hline C & 0.8613 \\
\hline RESID (-1) & 0.0698 \\
\hline
\end{tabular}

Sumber: Data Olahan (2021)

Berdasarkan nilai Probabilitas dari hasil woolridge test diperoleh 0,0698> 0,05 maka dapat dijelaskan bahwasanya pada riset ini tidak terjadinya autokorelasi.

Terdapat 55 data yang digunakan sebagai sampel yang berasal dari 11 Bank umum Syariah dari tahun 2015-2019. Setelah dilakukan beberapa macam uji dari variabel setiap independen terhadap variabel dependen maka memperoleh hasil sebagi berikut:

\section{Pengaruh Financing to Deposit Ratio (FDR) terhadap Profitabilitas Return On Asset (ROA)}

Pada hasil uji regresi liner berganda yang dilakukan memperoleh hasil akhir dari pengaruh Financing to Deposit Ratio (FDR) terhadap Profitabilitas (ROA) ialah Financing to Deposit Ratio (FDR) berpengaruh secara negatif terhadap Profitabilitas Return On Asset (ROA). Berdasarkan hasil hipotesis 1 penelitian ini selaras dengan penelitian yang dilakukan oleh (Hakiim \& Rafsanjani, 2018) dengan pernyataan bahwa Financing to Deposit Ratio (FDR) berpengaruh terhadap Profitabilitas Return On Asset (ROA) secara negatif.
Financing to Deposit Ratio (FDR) pada penelitian in memperoleh hasil berpengaruh secara negatif. Berpengaruh secara negatif bermakana bahwa ketika Financing to Deposit Ratio (FDR) mengalami peningkatan maka Roa mengalami penurunanan. Financing to Deposit Ratio (FDR) pada dasarnya rasio yang digunakan sebagai tolak ukur suatu perusahaan atau bank perihal dana pembiayaan yang ditarik oleh nasabah. Meningkatnya Financing to Deposit Ratio (FDR) membuktikan bahwa Financing to Deposit Ratio (FDR) memiliki dampak yang buruk terhadap Return On Asset (ROA). Hal ini disebabkan karena banyaknya pembiayaan yang dilakukan nasabah namun tingkat pengembalian yang diperoleh terbilang rendah sehingga menyebabkan terjadinya kolektabilitas yang tinggi. Kolektabilitas yang tinggi menjadi penyebab utama minimnya laba perolehan yang didapatkan.

\section{Pengaruh Debt to Equity Ratio (DER) terhadap Profitabilitas (ROA)}

Pada hasil uji regresi liner berganda yang dilakukan memperoleh hasil akhir tentang bagaimana pengaruh Debt to Equity Ratio (DER) terhadap Profitabilitas 
(ROA) ialah berpengaruh secara negatif. Penelitian ini sejalan dengan penelitian yang dilakukan oleh (Kamal, 2016) dan (Sofiani et al, 2018) yang menyatakan bahwa Debt to Equity Ratio (DER) bepengaruh terhadap Return On Asset (ROA) secara negatif.

Debt to Equity Ratio (DER) dalam penelitian ini didapatkan berpengaruh secara negatif. Berpengaruh secara negatif bermakna bahwa ketika perolehan Debt to Equity Ratio (DER) meningkat maka dapat memperkecil perolehan laba. Debt to Equity Ratio (DER) pada dasarnya merupakan rasio yang digunaan untuk membandingkan antara hutang dan ekuitas atau sering disebut sebagai rasio hutang modal. Peningkatan yang terjadi pada Debt to Equity Ratio (DER) membuktikan bahwa Debt to Equity Ratio (DER) memberikan efek yang buruk terhadap ROA dimana peningkatan ini bermakna bahwa hutang perusahaan lebih besar dibandingkan modal yang dimiliki perusahaan.

Hutang merupakan modal asing atau pendanaan eksternal yang digunakan untuk membantu operasional perusahaan dan harus dibayarkan saat jatuh tempo. Semakin singkat jangka waktu pembayaran maka semakin tinggi resiko pendanaan yang harus ditanggung. Resiko pendanaan seperti kecilnya aktiva lancar yang dimiliki sehingga tidak mampu memenuhi kewajiban yang ditanggung. Hal ini berdampak pada operasional perusahaan, operasional yang seharusnya dapat berjalan secara efektif untuk memperoleh laba menjadi tersendat. Ketika operasional mengalami masalah menandakan bahwa modal yang dimiliki tidak dimanfaatkan secara efisien sehingga mempengaruhi laba perolehan yang didapatkan. Debt to Equity Ratio (DER) bukan rasio yang memiliki pengaruh yang paling besar terhadap profitabilitas Return On Asset (ROA), karena masih terdapat faktor-faktor lain yang mempengaruhi profitabilitas Return On Asset (ROA), salah satunya pendapatan pada bank lain.

\section{Pengaruh Current Ratio (CR) terhadap Profitabilitas (ROA)}

Pada hasil uji regresi liner berganda yang dilakukan memperoleh hasil akhir bagaimana pengaruh Current Ratio (CR) terhadap Profitabilitas Return On Asset (ROA) ialah, Current Ratio (CR) berpengaruh secara positif terhadap profitabilitas (ROA). Hasil perolehan dari penelitian ini tidak sejalan dengan penelitian-penelitian terdahulu yang pernah dilakukan. Sehingga dapat menjadi referensi baru bagi peneliti berikutnya.

Current Ratio (CR) pada riset ini mempunyai pengaruh positif terhadap profitabilitas Return On Asset (ROA). Berpengaruh secara positif bermakna ketika Current Ratio (CR) mengalami peningkatan maka laba perolehan juga akan mengalami peningkatan. Hal ini disebabkan karena adanya pengaruh Current Ratio (CR) terhadap profitabilitas Return On Asset (ROA) yang berbanding lurus dan beriringan. Current Ratio (CR) pada dasarnya ialah rasio yang digunakan sebagai tolak ukur kemampuan perusahaan dalam menyelesaikan hutang jangka pendeknya. Peningkatan yang terjadi pada Current Ratio (CR) membuktikan bahwa Current Ratio (CR) memiliki efek yang cukup baik terhadap profitabilitas Return On Asset (ROA). Karena dapat merealisasikan pemanfaatan modal kerja yang dimiliki dengan optimal, sehingga tidak menyebabkan terjadinya penumpukan dana yang menganggur.

Penempatan modal telah dilakukan dengan efektif seperti dana yang ditentukan sebagai investasi dan dapat memperoleh laba perolehan yang baik bagi perusahaan. Rotasi perputaran modal kerja yang efisien dapat membuat laba perolehan mengalami peningkatan. Namun meskipun terdapat pengaruh 
secara positif, Current Ratio (CR) tidak memiliki pengaruh yang besar terhadap laba perusahaan. Karena masih terdapat faktor lain yang berpengaruh lebih besar terhadap seperti pembiayaan yang dilakukan oleh bank.

Pengaruh Financing to Deposit Ratio (FDR) terhadap Profitabilitas Return On Asset (ROA) yang Dimoderasi oleh Non Performing Financing (NPF).

Berdasarkan hasil dari uji Moderated Regression Analysis (MRA) yang telah dilakukan memperoleh hasil akhir dari riset ini berbanding terbalik dengan penelitian yang dilakukan oleh (Taufik, 2017) yang menyatakan bahwa Non Performing Financing (NPF) tidak dapat memoderasi antara Financing to Deposit Ratio (FDR) dengan Profitabilitas Return On Asset (ROA). Pernyataan yang didapat ialah Non Performing Financing (NPF) dapat memoderasi dengan memperkuat antara Financing to Deposit Ratio (FDR) dengan Profitabilitas Return On Asset (ROA) secara positif.

Pada hipotesis pertama Financing to Deposit Ratio (FDR) berpengaruh secara negatif terhadap Return On Asset (ROA), namun ketika Non Performing Financing (NPF) memoderasi keduanya, dapat memperkuat Financing to Deposit Ratio (FDR) terhadap Return On Asset (ROA). Perolehan riset ini berlandaskan pada nilai Financing to Deposit Ratio (FDR) dan NPF yang tinggi tidak secara langsung menyebabkan penurunan terhadap Return On Asset (ROA). Karena nilai Non Performing Financing (NPF) terbilang tinggi tidak akan mengganggu perputaran modal kerja dalam memperoleh keuntungan. Hal ini dikarenakan ketika Non Performing Financing (NPF) terbilang tinggi maka perusahaan akan menerapkan evaluasi terhadap operasional perusahaan dengan melakukan pemberhentian pada penyaluran pembiaayan untuk sementara waktu hingga nilai Non Performing Financing (NPF) dapat diturunkan.

Bukan hanya hal itu rata-rata perolehan Non Performing Financing (NPF) pada uji statistik didapati sebesar $4,390182 \%$ sehingga posisi Non Performing Financing (NPF) masih berada dikategori yang sehat pada peringkat ke-2 yaitu diantara $2-5 \%$ dapat diturunkan. Sehingga meskipun Financing to Deposit Ratio (FDR) dan NPF terbilang tinggi tetap mampu memperoleh keuntungan terhadap Return On Asset (ROA).

\section{Pengaruh Debt to Equity Ratio (DER) terhadap Profitabilitas yang Dimoderasi oleh Non Performing Financing (NPF).}

Berdasarkan hasil dari uji Moderated Regression Analysis (MRA) yang telah dilakukan memperoleh hasil akhir dari riset ini ialah Debt to Equity Ratio (DER) dinyatakan tidak mampu memoderasi antara Debt to Equity Ratio (DER) secara negatif. Riset ini memperoleh hasil bahwa Non Performing Financing (NPF) tidak bisa memoderasi Debt to Equity Ratio (DER) terhadap Profitabilitas Return On Asset (ROA). Hal ini berarti bank yang memiliki nilai Debt to Equity Ratio (DER) yang besar atau pun kecil tidak mempengaruhi perolehan Return on Asset (ROA) meskipun nilai Non Performing Financing (NPF) atau kredit macet terbilang besar ataupun kecil.

Pada perolehan Debt to Equity Ratio (DER) karena perusahan melakukan pembiayaan operasional yang menggunakan dana dari hutang modal dengan sangat hati-hati sehingga adanya dana cadangan yang digunakan untuk menutupi resiko yang terjadi.

\section{Pengaruh Current Ratio (CR) terhadap Profitabilitas yang Dimoderasi oleh Non Performing Financing}


Berdasarkan hasil dari uji Moderated Regression Analysis (MRA) yang telah dilakukan memperoleh hasil akhir dari riset ini menyimpulkan bahwasanya Non Performing Financing (NPF) mampu memoderasi dengan memperlemah antara pengaruh Current Ratio terhadap Profitabilitas.

Riset ini memperoleh hasil bahwa Non Performing Financing (NPF) mampu memoderasi Current Ratio (CR) terhadap Return On Asset (ROA). Hal ini dikarenakan ketika nilai Non Performing Financing (NPF) terbilang tinggi maka mampu menyebabkan efek penuruan nilai pada Current Ratio (CR) dalam memperoleh Return On Asset (ROA).

Pemanfaatan modal kerja menjadi tidak optimal karena banyaknya kredit macet yang terjadi, sehingga menyebabkan minimnya laba perolehan yang dihasilkan. Dana untuk operasional yang seharusnya dapat dimanfaatkan sebaik mungkin menjadi terkendala karena adanya kredit macet lalu terjadilah rotasi modal kerja menjadi tidak efektif. Karena rotasi modal kerja tidak dipergunakan dengan efisien maka mengakibatkan penurunan ketika memperoleh laba.

\section{KESIMPULAN}

Berdasarkan hasil perolehan pada riset ini dapat disimpulkan bahwasanya penggunaan variabel Financing to Deposit Ratio (FDR), Debt to Equity Ratio (DER) berpengaruh kearah negatif dan Current Ratio (CR) berpengaruh kearah positif terhadap Return On Asset (ROA). Meskipun pada varibel Current Ratio (CR) dapat memiliki pengaruh yang positif namun Current Ratio (CR) tidak memiliki dampak yang cukup besar terhadap Return On Asset (ROA). Pada varibel pemoderasi yaitu Non Performing Financing (NPF) dapat dijadikan sebagai peninjau dalam memperoleh kentuntungan terutama ketika Non Performing
Financing (NPF) mampu memperkuat Financing to Deposit Ratio (FDR) terhadap Return On Asset (ROA) meskipun dalam perolehan keuntungan harus dilakukan pemberhentian penyaluran pembiayaan secara sementara. Selain itu perlu dilakukannya peninjauan terhadap pengaruh Current Ratio (CR) pada Return On Asset (ROA) ketika dimoderasi oleh Non Performing Financing (NPF) karena dapat memperlemah dalam memperoleh laba. Sedangkan Debt to Equity Ratio (DER) tidak dapat dimoderasi oleh Non Performing Financing (NPF) dalam memperoleh Return On Asset (ROA).

\section{DAFTAR PUSTAKA}

Asyik, N. F. 2016. Perspektif Agency Theory: Pengaruh Informasi Asimetri Terhadap Manajemen Laba (Menggunakan Pendekatan Agency Framework). EKUITAS (Jurnal Ekonomi Dan Keuangan), 4(1), p. 29-42.

Hakiim, N, \& Rafsanjani, H. 2018. Pengaruh Internal Capital Adequency Ratio (CAR), Financing To Deposit Ratio (FDR), Dan Biaya Operasional Per Pendapatan Operasional (BOPO) Dalam Peningkatan Profitabilitas Industri Bank Syariah Di Indonesia. Mega Aktiva: Jurnal Ekonomi Dan Manajemen, 7(1), p. 161-168.

Ikhwal, N. 2016. Analisis ROA Dan ROE Terhadap Profitabilitas Bank Di Bursa Efek Indonesia. Al-Masraf: Jurnal Lembaga Keuangan Dan Perbankan, 1(2), p. 211-227.

Jungjungan, P. D. E. M. S., Surono, S. E., \& Sejati, P. E. 2015. Analisis Likuiditas Dan Leverage Terhadap Profitabilitas Perusahaan Yang Terdaftar. Di kutip dari : file:///C:/Users/User/Downloads/3 07-894-1-SM\%20(1).pdf 
Kamal, M. B. 2016. Pengaruh Receivable Turn Over Dan Debt To Asset Ratio (DAR) Pada Perusahaan Pertanian Yang Terdaftar Di Bursa Effek. Jurnal Ilmiah Manajemen Dan Bisnis, 17(02), p. 68-81.

Kasmir. 2014. Bank dan Lembaga Keuangan Lainnya. Rajawali Pers. Jakarta.

Maysarah, \& Kharisma, Fandi. 2020. Pengaruh Financing to Deposit Ratio ( FDR ) Terhadap Return on Assets (ROA) pada Perbankan Syariah. Borneo Student Research, 1(2), p. 1016-1023.

Almunawwaroh, Medina., \& Marliana, Rina. 2018. Pengaruh CAR, NPF dan FDR Terhadap Profitabilitas Bank Syariah Di Indonesia. Amwaluna: Jurnal Ekonomi dan Keuangan Syariah, 2(1), p. 1-18,

Martiningtiyas, C. R., \& Nitinegeri, D. T. 2020. The Effect of NonPerforming Loans on Profitability in Banking Sector in Indonesia. Proceedings of the International Conference on Management, Accounting, and Economy (ICMAE).

Otoritas Jasa Keuangan. 2019. Statistik Perbankan Syariah. Jakarta.

Palimbong, L. M. 2016. Pengaruh Current Ratio dan Debt to Equity Ratio terhadap Tingkat ROA pada Perusahaan Sektor Konstruksi yang Terdaftar di Bursa Efek Indonesia (BEI). Skripsi. Fakultas Ekonomi Universitas Negeri Makassar.

Putranta, E. A. H, \& Ambarwati, L. 2019. Pengaruh Faktor-Faktor Internal Perbankan Terhadap Non Performing Financing Pada Bank Umum Syariah. Jurnal Riset Manajemen Sekolah Tinggi Ilmu
Ekonomi Widya Wiwaha Program Magister Manajemen, 6(2), p. 115130.

Riyanto, B. 1998. Dasar Dasar Pembelanjaan Perusahaan (4th ed.). BPFE. Yogyakarta.

Sofiani, R., Hariyanto, Dedi., \& Safitri, Heni. 2018. Pengaruh TATO, FATO, DAR, dan DER Terhadap ROA pada Indeks IDX30 yang Terdaftar di Bursa Efek Indonesia. Jurnal Produktivitas, 5(1), p. 69-73.

Saragih, M. 2015. Pengaruh Current Ratio Terhadap Return On Asset Pada Perusahaan Sektor aneka Industri. Jurnal Financial, 1(1), p. 19-24.

Sari, N. M. V, \& Budiasih, I. G. A. 2014. Pengaruh Debt To Equity Ratio, Firm Size, Inventory Turnover Dan Assets Turnover Pada Profitabilitas. E-Jurnal Akuntansi Universitas Udayana, 6(2), $\mathrm{p}$. 261-273.

Taufik, M. 2017. Pengaruh Financing To Deposit Ratio Dan Capital Adequacy Ratio Terhadap Return on Asset dengan Non Performing Financing Sebagai Variabel Moderasi Pada Bank Umum Syariah Di Indonesia. AtTawassuth, 2(1), p. 170-190. 